\title{
Mobile Learning Application Design to Promote Youth Financial Management Competency in Thailand
}

\author{
https://doi.org/10.3991/ijim.v13i12.11367
}

\author{
Alisa Mueangpud, Jintavee Khlaisang $\left.{ }^{(}{ }^{凶}\right)$, Prakob Koraneekij \\ Chulalongkorn University, Bangkok, Thailand \\ jintavee.mechula.ac.th
}

\begin{abstract}
Financial knowledge is an important factor in a country's economic and financial security and its citizens' lives and there is much related research indicating that technology will help, especially in the case for the mobile learning application model. This has the potential to educate and for the knowledge to be shared via the social network and social share and for the student to access vast learning sources to cultivate appropriate habits in financial management as they grow up. The purpose of the study was to design and develop a mobile application, including confirmatory factor analysis to learn and promote youth's financial management competency. This study used mixed methods in research both quantitative and qualitative approaches to explore research by collecting the comments from 5 regions in Thailand totaling 957 students and the qualitative data of 10 teachers by interviews. The results found that $98.75 \%$ of students had a smart mobile phone and that the students need a mobile application which can be used for learning everywhere $(64.89 \%)$, supporting smart mobile phones both iOS system (Apple) and Android (66.04\%), mobile learning design consisting of infographics, animation, sound and video $(65.41 \%)$, The respondents needed the scaffolding application that is both flexible and fixed at the highest level $(67.50 \%)$ and scenario-based learning in daily life at the $(84.64 \%)$ and a financial pretest which motivated mobile application learning.
\end{abstract}

Keywords - Financial Management Competency, Mobile Application, Mobile Learning, Mobile Scaffolding Application, Scenario-Based Learning

\section{$1 \quad$ Introduction}

The mission of the Organization for Economic Co-operation and Development (OECD) is to coordinate nations around the world such as G20 and Asia-Pacific Economic Co-operation: APEC. Its goals are to promote financial knowledge and proceed with the national strategy of financial knowledge [1], [2]. With the rapidly changing global situation, one necessary skill for life is financial knowledge and this seems particularly important for children in the future as well as the country's economy and financial security according to the theory of endogenous growth which emphasises the importance of saving and investment [3] as a factor behind sustainable economy 
growth for long periods. At present, the world is changing to a digital economy [4] which promotes the new business of FinTech (financial technology) and EDTECH (Education Technology) will upgrade education through new technology that opens up equal opportunities to access data as well as reduce the inequalities in education by equipping learners with the life skills of financial management suitable for the rapidly changeable economic and social situation. In addition, now is the period of Gen Mobile in which mobile appliance such as smart phones and tablet $\mathrm{s}$ have become part of our daily lives and people can connect and exchange data by the internet [5].

From a survey of financial knowledge, overall it was found that students of primary, high school and at university level had the lowest scores [1], [2]. The government should provide and present financial information on media such as the mobile phone, $\mathrm{TV}$, radio and internet [6]. Good financial status is an important factor which shows the good living of the family and macro economy. The main subjects and skills for living in the 21 st century are the Financial, Economic, Business and Entrepreneurial Literacy [3]. The present teaching method is that students must be free to learn technology, think and make mistakes freely. Therefore, a mobile application is suitable for new generations to study everywhere and also attract their attention because education applications are being continuously developed which greatly affects people's lives and the trend towards mobile application usage is increasing [7]. Financial management learning is not done easily by only context reading, but learners must learn by scenario-based learning which assists them in interpreting and applying the relevant knowledge in their daily lives [8].

From the above problem and the supporting reasons from the conceptual framework and research results, This study aimed to design and develop a mobile application to promote learning competency by learning ideas following the scenario-based learning to promote financial management. The research questions were: 1) what is the need and mobile learning application design leading to mobile application development for financial management, and 2) what are the confirmatory factors which develop and promote financial management competency improving the lives of learners and driving economic development in the country, including application to real life and their security in the future.

\section{Literature Review}

\subsection{Mobile learning}

Mobile learning is the form of learning by mobile phone which at present is applied widely with the number of users increasing every year for the reason that learners can access the internet network easily and conveniently, especially mobile applications [9]. Mobile learning is a method of learning that can be easily accessed by the new generation, allowing users to access it anywhere, anytime, while also being applied to daily life [10]. The form of mobile learning increases learning competency due to convenience and speed as the learners are able to access and hold the mobile phone at all times [11]. 
The structure and critical factors of mobile learning comprise 5 factors: 1) M-LMS (Mobile Learning Management System) is the learning system covering the context integrating the data and source for mobile learning. 2) M-content is the context in which mobile learning is used. 3) MCMS (Mobile Content Management System) manages the context as the tool context management for M-learning. 4) M-testing is the part of the test to evaluate learning which is separated into pre-tests and post-tests. 5) Mlearners refers to M-learning learners which includes every group of users who study the lessons in the system (see Figure 1) [12], [13].

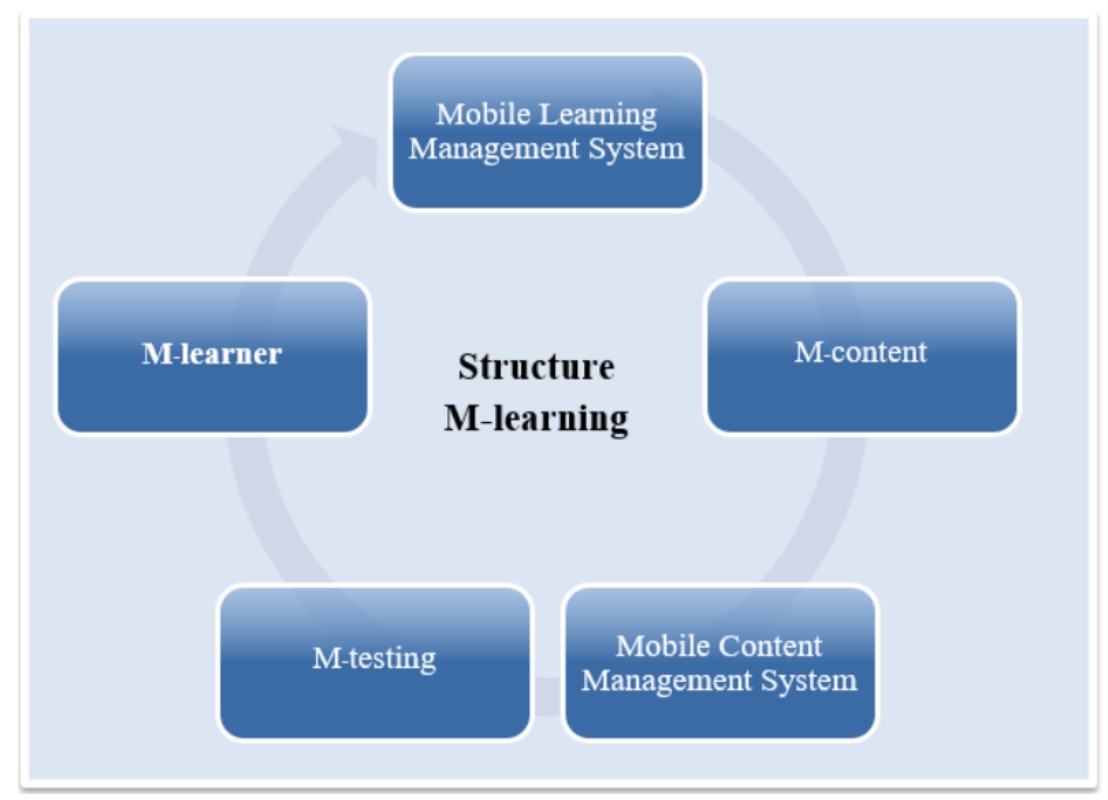

Fig. 1. Five critical factors of mobile learning

The factors of mobile learning comprise the following:

- Access and stimulus: What causes the people to be stimulated is that learners can expect the subject to be of high value and one that can lead them to success

- Organism response

- Interaction: Social interaction is the reaction, the 1 st reaction refers to the reaction to the context of the mobile application, the 2 nd reaction refers to the reaction among the consumers who apply the application or the consumers and application services

- Learning activities

- Learning sources

- Evaluation is to measure and assess the test of knowledge (see Figure 2) [14]. 


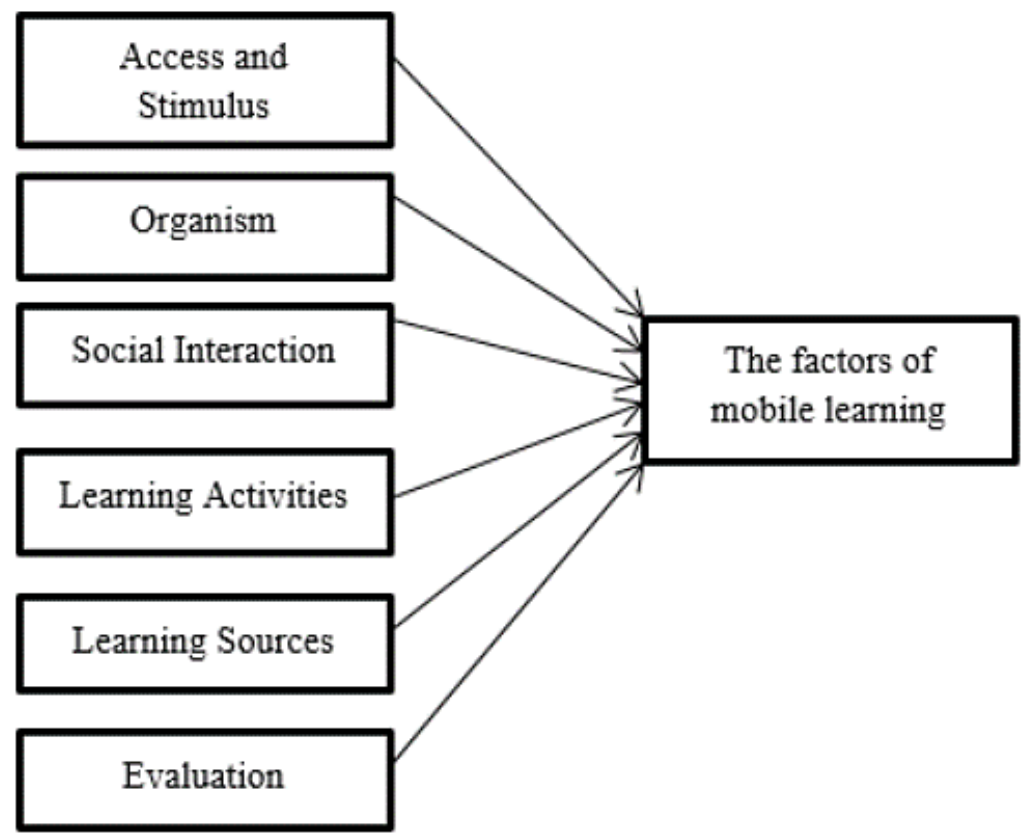

Fig. 2. The architecture of financial mobile application

\subsection{Mobile applications promote financial management}

A mobile application is software developed and designed for a special function to be used with a small wireless appliance [14] and which can be accessed by the new generation. In addition, the mobile service is convenient for use at any time and can cultivate the habit of financial management as the new generation grow up and apply it to their lives [15]. A mobile application was developed with simple features but sufficient for effective learning for this specific research. The interface was made to meet the needs of users as well as utilise various types of media such as text, images, animation and video [16].

Technology can assist student learning [17]. The form of learning on the mobile application is that of technology learning theory which may form the basis of mobile learning and which identifies six related theories: behaviorist, constructivist, situated, lifelong and informal, collaborative learning, and learning and teaching support. One of the biggest challenges is the integration of daily life learning with mobile phone technology [18], [21].

Mobile application development on the mobile phone involves difficult architecture and a different environment of a high-speed growth technology cycle. Development comprises these steps: analyze, design, develop, certify app store certification and deploy \& maintain (see Figure 3) [17] 


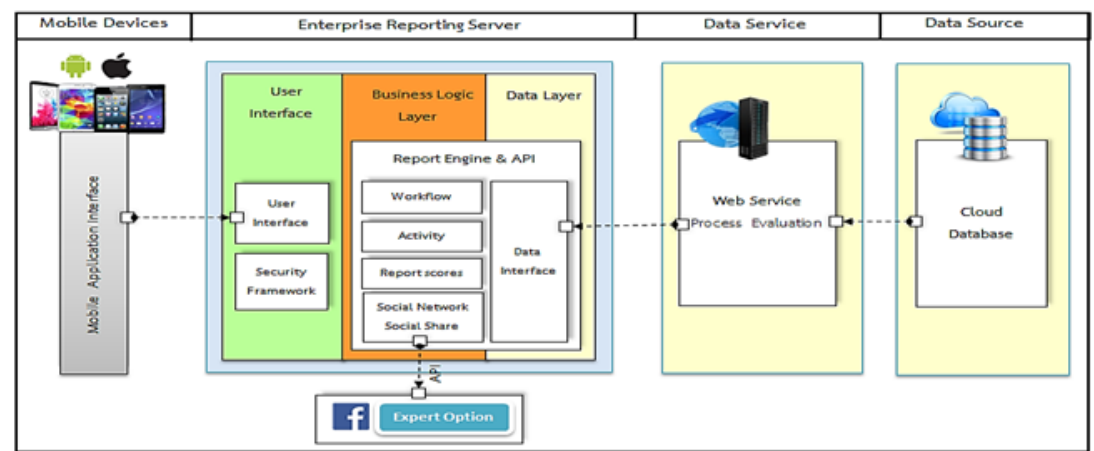

Fig. 3. The architecture of financial mobile application

\section{$3 \quad$ Methodology}

\subsection{The sampling and the procedure}

This study adopted a mixed method with survey and interview using a multistage sampling. First, the finished table was calculated according to the formula of Cohen et al. (2001) [22]. The sample consisted of 980 male and female students aged 15-17 years old and studying in the senior high school, as well as ten teachers who were interviewed. Each interview lasted 30 minutes. Second, the sample group was selected by cluster sampling. The researchers collected the data of the questionnaires from the cluster sampling of 5 regions in Thailand, namely the North, North-East, Central, East and South. Finally, the sampling was a stratified random sample from public and private schools. The 980 questionnaires, a 100\% response rate, were collected and 957 questionnaires, or $97.65 \%$, qualified for the research. Furthermore, the researchers interviewed the ten teachers about the teaching situation by purposive selection using the following criteria:

- The teachers must work with the Office of the Basic Education

- The teachers must have at least 5 years of teaching experience in financial management

- The teachers cooperated in doing the research via face-to-face interviews. Each interview lasted 30 minutes

\subsection{Questionnaire \& interview form}

The research instruments used in this study were a questionnaire used for collecting quantitative data and structured interview The questionnaires were separated into 3 parts:

- The general information of the respondent 
- Confirmatory factor analysis of financial management competency

- The comments and necessary demands for the design and mobile application development to promote the financial management among youths with variables on a 5-point Likert scale.

Rating each level between 1-5 with 1 being not at all needed, Level 2 slightly needed, Level 3 moderately needed, Level 4 very much needed and Level 5 extremely needed. The topic and questions in the questionnaires were discussed and certified by mobile application technology and financial management experts for analysis of the Index of Item Objective Congruence (IOC) by setting the considered criteria to be of good content validity (IOC > 0.50) [22]. Examples questions included the follows: "How is the application ready for learning ?" , "What learning design application is easy to understand and interesting?", etc.

A structured interview a formal asking about the Teaching and learning which affected financial management and moderately scheduled interview in which the questions were prepared in advance with the questions extended or new questions as appropriate during the interviews. [23] The scope of the interview was wide covering issues about the students' teaching of financial management competency and the teachers' comments and data inspection from the research. Examples questions include the following: "What is the starting point?", "Why does it help to strengthen the financial management competency?", "What do you think the steps should be to develop the teaching of students in the performance of financial management?", Appropriate media technology? Precautions and instructions for processing? ", etc.

\subsection{Data analysis}

The statistics of research were frequency, percentage, MEAN, SD, PNI [23], Pearson product-moment correlation coefficient, confirmatory factor analysis (CFA) by LISREL program [24] and interview content analysis.

\section{$4 \quad$ Results}

\subsection{Demographic information}

The sample group consisted of 957 students of high school level and teachers with 5-10 years teaching experience. As can be seen in Table 1, most students were female $(62.5 \%)$, followed by male $(37.5 \%)$, of which 257 students $(26.9 \%)$ were aged 15 years, 345 students (36.1\%) aged 16 years, and 355 students aged 17 years. The average student was studying in senior high school in levels 4 and 5 and the average grade of 39 high school students was lower or equal to $2.00(41 \%), 161$ students between 2.01-2.50 (16.8\%), 246 students between 2.51-3.00 (25.7\%) and 272 students between $3.51-4.00(28.4 \%)$.

The study target group was located in 5 regions in Thailand consisting of the Central, Northern, Southern, Eastern and North-Eastern regions. The amount of students 
who applied the mobile application were as follows: Android 486 students (50.8\%), iOS (Apple) 424 students (44.3\%), iOS (Apple) and Android 30 students (3.1\%), iOS (Apple), Android and Windows Phone 10 students (1.0\%), and Windows Phone 7 students $(0.7 \%)$. The time students spent on applications was as follows: 423 students (44.2\%) more than 5 hours/day, 197 students (20.6\%) 1-3 hours/day, 162 students (16.9\%) 4 hours/day, 147 students (15.4\%) 5 hours/day and 28 students (2.9\%) 0-1 hours/day. Regarding the mobile network, 641 students used 1G, 2G, 3G, 4G, Wi-Fi (67\%), 230 students used 1G, 2G, 3G, 4G (24\%), 77 students used Wi-Fi (8\%) and 9 students did not use the internet $(0.9 \%)$.

Table 1. Demographic $(n=957)$

\begin{tabular}{|c|c|c|c|}
\hline \multicolumn{2}{|c|}{ Construct } & Number & Percent \\
\hline \multirow{2}{*}{ Gender } & Male & 359 & $37.5 \%$ \\
\hline & Female & 598 & $62.5 \%$ \\
\hline \multirow{3}{*}{ Age } & 15 & 257 & $26.9 \%$ \\
\hline & 16 & 345 & $36.1 \%$ \\
\hline & 17 & 355 & $37.1 \%$ \\
\hline \multirow{5}{*}{$\begin{array}{l}\text { Cumulated average grade } \\
\text { (high school) }\end{array}$} & Lower or equal 2.00 & 39 & $4.1 \%$ \\
\hline & $2.01-2.50$ & 161 & $16.8 \%$ \\
\hline & $2.51-3.00$ & 239 & $25.0 \%$ \\
\hline & $3.01-3.50$ & 246 & $25.7 \%$ \\
\hline & $3.51-4.00$ & 272 & $28.4 \%$ \\
\hline \multirow{5}{*}{ Mobile application systems } & iOS (Apple) & 424 & $44.3 \%$ \\
\hline & iOS (Apple), Android & 30 & $3.1 \%$ \\
\hline & $\begin{array}{l}\text { iOS (Apple), Android, Windows } \\
\text { Phone }\end{array}$ & 10 & $1.0 \%$ \\
\hline & Android & 486 & $50.8 \%$ \\
\hline & Windows Phone & 7 & $0.7 \%$ \\
\hline \multirow{5}{*}{ Period of mobile usage } & $0-1$ hours & 28 & $2.9 \%$ \\
\hline & $1-3$ hours & 197 & $20.6 \%$ \\
\hline & 4 hours & 162 & $16.9 \%$ \\
\hline & 5 hours & 147 & $15.4 \%$ \\
\hline & 5 hours up & 423 & $44.2 \%$ \\
\hline \multirow{4}{*}{ Internet network } & 1G, 2G, 3G, 4G, Wi-Fi & 641 & $67.0 \%$ \\
\hline & $1 \mathrm{G}, 2 \mathrm{G}, 3 \mathrm{G}, 4 \mathrm{G}$ & 230 & $24.0 \%$ \\
\hline & Wi-Fi & 77 & $8.0 \%$ \\
\hline & No internet & 9 & $0.9 \%$ \\
\hline
\end{tabular}

\subsection{Questionnaire responses}

Figure 4. shows the percentage of devices that students use as learning media, First was the smart-phone (945 students - 98.75\%), second was the notebook (512 students $-53.50 \%$ ), third was the desktop computer (431 students $-45.04 \%$ ), and last was 
tablet (234 students $-24.45 \%$ ). The above findings confirm that most students primarily use a smart-phone. As regards mobile phone application use, this was for making and receiving calls, finding learning sources, social network : Line Facebook Instagram Twitter, camera and video, YouTube, TV Online, playing games, and listening to music (649 of 957 students, or $67.82 \%$ ) (see Table 2). The researchers therefore invented and developed a mobile learning application design to promote youth financial management competency. The design also had to meet the needs of today's students who have a smart phone with them at all times and use it to learn and exchange knowledge through social networks, to research, and find convenient and easy-to-use learning sources. This is because the smartphone is now embedded within everyday life.

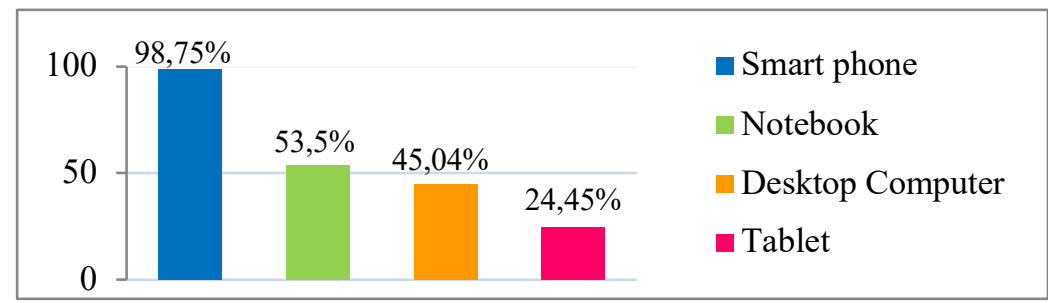

Fig. 4. Devices students used

Table 2. 5 priorities of mobile phone usage among students $(n=957)$

\begin{tabular}{|l|c|c|c|}
\hline \multicolumn{1}{|c|}{ Mobile phone usage among students } & Frequency & Percent & Rank \\
\hline $\begin{array}{l}\text { First was for making and receiving calls, find learning sources, social net- } \\
\text { work : Line Facebook Instagram Twitter, camera and video, YouTube, TV } \\
\text { Online, playing games, music listening. }\end{array}$ & 649 & 67.82 & 1 \\
\hline $\begin{array}{l}\text { Second was for making and receiving calls, social network : Line Facebook } \\
\text { Instagram Twitter, photo and video, TV Online, music listening. }\end{array}$ & 100 & 10.45 & 2 \\
\hline $\begin{array}{l}\text { Third was for making and receiving calls, find learning sources, camera and } \\
\text { video, playing games. }\end{array}$ & 46 & 4.81 & 3 \\
\hline $\begin{array}{l}\text { And fourth was for making and receiving calls, find learning sources, social } \\
\text { network : Line Facebook Instagram Twitter, YouTube, TV Online, music } \\
\text { listening. }\end{array}$ & 43 & 4.49 & 4 \\
\hline $\begin{array}{l}\text { Last was for making and receiving calls, find learning sources, social net- } \\
\text { work: Line Facebook Instagram Twitter, playing games, YouTube, TV } \\
\text { Online, music listening. }\end{array}$ & 29 & 3.03 & 5 \\
\hline
\end{tabular}

4.3 The research results for research question 1: The need of a mobile learning application to the design and mobile application development for financial management competency

Questionnaire responses results shown in Table 3 suggests that in order to answer the first research question, the sample group's questionnaire to all 957 students provided comments about the need of a mobile application for financial management competency. Most respondents (64.89\%) need the application for learning at any place and any time and required an application which can be used with Apple and 
Android systems at the highest level (66.04\%). The respondents required a learning application design on multimedia with text, infographics, animation, sound and video to be intelligible and more interesting at the highest level (65.41\%) and needed exercises for the financial pretest to stimulate their motivation and application learning at the highest level (73.67\%), followed by mobile application suggestions $(31.35 \%)$, needed the main menu at the left side for convenience and ease of use at the highest level $(36.89 \%)$, and at present they were asked what they selected, and they required mobile application learning on an online social network, data change, knowledge creation at the highest level $(65.31 \%)$. The respondents would like the financial experts to be more comprehensive about the financial knowledge, therefore the experts were needed for advice on applications at the highest level $(60.29 \%)$ and needed the advisors every time if they did not understand at the highest level $(52.46 \%)$. The respondents needed the communication channel to contact with expert by web board the question-answer $(44.10 \%)$, and needed the scaffolding application that is both soft scaffolding and hard scaffolding $(67.50 \%)$, followed by hard scaffolding only $(56.63 \%)$. The respondents needed scenario-based learning at the highest level $(84.64 \%)$. The respondents shared the problem solutions with friends on Facebook at the highest level $(69.17 \%)$. The results are presented in Table 3. Therefore, the researcher used the questionnaire responses in the design and development of a Mobile Scaffolding Application in Scenario-Based Learning to Promote Youth Financial Management Competency (see Figure 6 and 7).

Table 3. Comments on the need and the present situation of the preferred practice for design and mobile learning application development

\begin{tabular}{|c|c|c|c|c|c|c|}
\hline \multirow[t]{2}{*}{ Items } & \multicolumn{5}{|c|}{$\begin{array}{c}\text { The need to design mobile learning } \\
\text { on financial management }\end{array}$} & \multirow[t]{2}{*}{ Rank } \\
\hline & Level 1 & Level 2 & Level 3 & Level 4 & Level 5 & \\
\hline \multicolumn{7}{|l|}{ 1. How is the application ready for learning? } \\
\hline A. Learning anywhere and anytime. & 1.78 & 4.60 & 10.14 & 18.60 & 64.89 & 1 \\
\hline B. Learning in class only. & 27.69 & 20.17 & 29.68 & 14.52 & 7.94 & 3 \\
\hline C. Learning on internet connect only. & 18.29 & 11.91 & 23.41 & 21.42 & 24.97 & 2 \\
\hline \multicolumn{7}{|c|}{ 2. What is the application supporting smart mobile phone? } \\
\hline A. $\mathrm{iOS}$ (Apple) & 10.66 & 4.28 & 15.99 & 20.79 & 48.28 & 2 \\
\hline B. & 6.69 & 4.81 & 17.45 & 25.39 & 45.66 & 3 \\
\hline $\mathrm{C}$ & 7.73 & 4.39 & 10.34 & 11.49 & 66.04 & 1 \\
\hline \multicolumn{7}{|c|}{ 3. Which learning design on application is easy to understand and interesting? } \\
\hline $\begin{array}{l}\text { A. Multimedia with infographic, anima- } \\
\text { tion, sound and video }\end{array}$ & 1.99 & 2.72 & 11.08 & 18.81 & 65.41 & 1 \\
\hline B. Infographic and photo & 3.66 & 6.58 & 29.15 & 32.29 & 28.32 & 2 \\
\hline C. Text only & 34.69 & 25.29 & 22.99 & 8.15 & 8.88 & 3 \\
\hline \multicolumn{7}{|c|}{ 4. Which function will stimulate your motivation of learning application? } \\
\hline $\begin{array}{l}\text { A. The suggestion of mobile application } \\
\text { usage. }\end{array}$ & 5.85 & 8.99 & 25.08 & 28.74 & 31.35 & 2 \\
\hline
\end{tabular}




\begin{tabular}{|c|c|c|c|c|c|c|}
\hline \multirow[t]{2}{*}{ Items } & \multicolumn{5}{|c|}{$\begin{array}{c}\text { The need to design mobile learning } \\
\text { on financial management }\end{array}$} & \multirow[t]{2}{*}{ Rank } \\
\hline & Level 1 & Level 2 & Level 3 & Level 4 & Level 5 & \\
\hline B. Inspiration word for money saving. & 6.06 & 12.23 & 33.33 & 28.00 & 20.38 & 3 \\
\hline $\begin{array}{l}\text { C. Mockup of Financial exercise for } \\
\text { Pretest. }\end{array}$ & 3.76 & 6.48 & 8.57 & 7.52 & 73.67 & 1 \\
\hline \multicolumn{7}{|c|}{ 5. Which design of main menu is convenient and easy usage? } \\
\hline A. menu on the left side & 5.96 & 8.15 & 24.45 & 24.56 & 36.89 & 1 \\
\hline B. menu on the upper side & 6.48 & 9.40 & 25.91 & 29.15 & 29.05 & 2 \\
\hline C. menu on the bottom side & 15.15 & 14.84 & 29.05 & 21.11 & 19.85 & 3 \\
\hline \multicolumn{7}{|c|}{ 6. What design of mobile learning application would you like? } \\
\hline $\begin{array}{l}\text { A. Social network online for data ex- } \\
\text { change building }\end{array}$ & 1.15 & 2.30 & 10.87 & 20.38 & 65.31 & 1 \\
\hline $\begin{array}{l}\text { B. Social network online for data ex- } \\
\text { change }\end{array}$ & 1.88 & 4.81 & 26.33 & 47.23 & 19.75 & 3 \\
\hline C. Social network online & 8.57 & 13.06 & 36.26 & 20.90 & 21.21 & 2 \\
\hline \multicolumn{7}{|c|}{ 7. To increase the financial learning knowledge, the function of expert should advise. } \\
\hline A. Financial experts & 1.88 & 3.97 & 14.11 & 19.75 & 60.29 & 1 \\
\hline B. Instructors & 3.55 & 6.06 & 22.47 & 41.38 & 26.54 & 2 \\
\hline C. Friends & 13.58 & 21.53 & 30.62 & 21.32 & 12.96 & 3 \\
\hline \multicolumn{7}{|c|}{ 8. The frequency of communication with application experts. } \\
\hline $\begin{array}{l}\text { A. Every time or all the time in case you } \\
\text { do not understand. }\end{array}$ & 7.73 & 9.93 & 9.51 & 20.38 & 52.46 & 1 \\
\hline B. One time/one topic & 9.82 & 12.96 & 24.66 & 35.95 & 16.61 & 2 \\
\hline C. One time $/ 2$ topics & 15.78 & 16.20 & 32.60 & 25.18 & 10.24 & 3 \\
\hline \multicolumn{7}{|c|}{ 9. Communication channel to contact with expert. } \\
\hline A. Web board (question-answer) & 4.49 & 9.72 & 18.50 & 23.20 & 44.10 & 1 \\
\hline B. Consult by E-mail & 8.78 & 13.58 & 30.41 & 28.84 & 18.39 & 3 \\
\hline C. Consult by telephone & 10.55 & 12.85 & 22.78 & 22.26 & 31.56 & 2 \\
\hline \multicolumn{7}{|c|}{ 10. How do you want the assistance on mobile scaffolding application from financial experts? } \\
\hline A. Soft Scaffolding & 3.34 & 4.49 & 21.00 & 56.53 & 14.63 & 3 \\
\hline B. Hard Scaffolding & 3.55 & 9.72 & 34.80 & 32.08 & 19.85 & 2 \\
\hline $\begin{array}{l}\text { C. Both soft scaffolding and hard scaf- } \\
\text { folding }\end{array}$ & 5.33 & 7.42 & 10.14 & 9.61 & 67.50 & 1 \\
\hline \multicolumn{7}{|c|}{ 11. How is the scenario-based learning promoting the financial knowledge? } \\
\hline A. Situation in daily life & 1.78 & 2.19 & 8.67 & 2.72 & 84.64 & 1 \\
\hline B. Situation in drama & 9.61 & 16.72 & 33.75 & 28.42 & 11.49 & 3 \\
\hline C. Situation in cartoon & 17.87 & 17.76 & 32.29 & 16.72 & 15.36 & 2 \\
\hline \multicolumn{7}{|c|}{ 12. After solution, which media do you want to present your job and share with your friends? } \\
\hline $\begin{array}{l}\text { A. Share the problem solution direction } \\
\text { with your friends on web board. }\end{array}$ & 5.64 & 8.99 & 24.14 & 29.15 & 32.08 & 2 \\
\hline $\begin{array}{l}\text { B. Share the problem solution direction } \\
\text { with your friends on Facebook. }\end{array}$ & 0.94 & 5.43 & 7.52 & 16.93 & 69.17 & 1 \\
\hline C. No sharing & 28.94 & 17.97 & 23.82 & 13.79 & 15.46 & 3 \\
\hline
\end{tabular}


Rating each level between 1-5 with 1 being not at all needed, Level 2 slightly needed, Level 3 moderately needed, Level 4 very much needed and Level 5 extremely needed.

\subsection{Readiness and priorities for the needs that influence intentions to use mobile learning}

When considering need, it was found that the respondents needed to record their daily income expenses on their mobile application at the highest level (PNIModified $=$ 0.80), followed by the respondents needing to set up a long-term financial target and trying to achieve their target (PNIModified $=0.21$ ). They needed to realize whether they had enough money to buy something (PNIModified $=0.16)$. They needed to learn more about mobile scaffolding applications and therefore the financial expert should advise. (PNIModified $=0.15$ ). Finally, the least need was scenario-based learning in their daily lives which promoted their financial knowledge (PNIModified $=0.12$ ) (Table 4).

Table 4. The 5 priorities for the needs of mobile application learning by scenario-based learning to promote financial management competency $(n=957)$

\begin{tabular}{|c|c|c|c|c|c|}
\hline \multirow{2}{*}{ Description } & \multirow{2}{*}{ 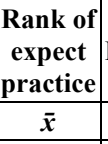 } & \multicolumn{2}{|c|}{ Rank of practice } & \multirow{2}{*}{$\begin{array}{c}\text { PNIModi- } \\
\text { fied }\end{array}$} & \multirow{2}{*}{$\begin{array}{c}\text { Rank of } \\
\text { re- } \\
\text { quire- } \\
\text { ment }\end{array}$} \\
\hline & & $\overline{\boldsymbol{x}}$ & $S D$ & & \\
\hline $\begin{array}{l}\text { You record your income and expenses daily on mobile } \\
\text { application phone. }\end{array}$ & 5 & 2.78 & 1.58 & 0.80 & 1 \\
\hline $\begin{array}{l}\text { You set the longterm financial target and try to achieve the } \\
\text { target. }\end{array}$ & 5 & 4.12 & 4.12 & 0.21 & 2 \\
\hline $\begin{array}{l}\text { Before buying something, your realized whether you can } \\
\text { afford. }\end{array}$ & 5 & 4.30 & 0.99 & 0.16 & 3 \\
\hline $\begin{array}{l}\text { More understanding the scaffolding application, the finan- } \\
\text { cial experts will be advisor. }\end{array}$ & 5 & 4.33 & 0.98 & 0.15 & 4 \\
\hline $\begin{array}{l}\text { You learn the scenario-based learning in your daily life to } \\
\text { increase your financial knowledge. }\end{array}$ & 5 & 4.48 & 0.88 & 0.12 & 5 \\
\hline
\end{tabular}

\subsection{User interface prototypes on mobile learning financial management}

The Results shown in Table 2 and Fig. 6 can be utilized in the user interface design (UI) and user experience design (UX), to be in line with user experience, suitable for the financial management of youth mobile users. The main objective is simple design using a little personal skill. The sequence of steps to use the program must not be complicated and be able to properly support the amount of incoming and outgoing data.

For the mobile learning financial management, the screen is designed with a clear menu suitable for fingers. The touch menu is arranged in a hierarchical order and divided into different submenus for ease of use [25]. The findings of this study, like other studies, suggested findings show that the recommended function menu be one of icons and symbols to suit learners. Such features are extremely important, affecting 
both the ability of the learner to easily understand and interact with the content [25],[26] (see Figure 5b and 6a). Thus, the student must understand the display format easily, including the design of the operating screen aesthetically appealing. Also, more importantly, when using the system the standard of using commands that must be both the same and fun must be considered via designing an interface that is shared through the social network menu to interact and exchange view with others. Presentations include text, images, audio and multimedia, making it easy for learners to understand (see Figure 6b), so the designs of the user interface prototypes following the respondents' suggestions as shown in Figure 5 and 6.

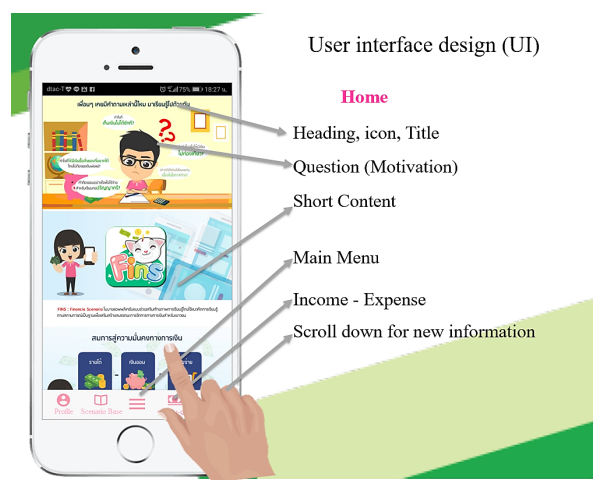

a

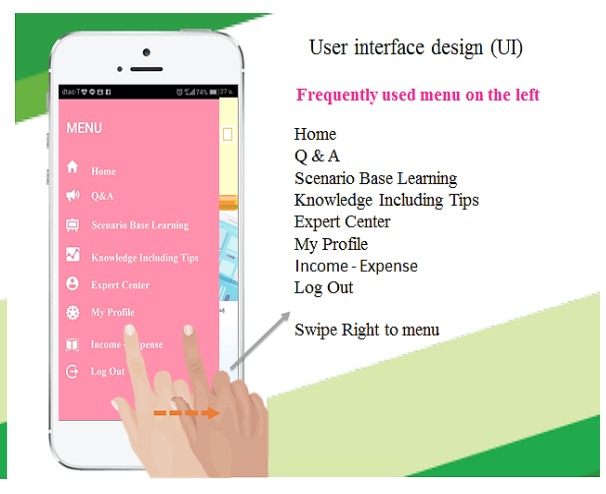

b

Fig. 5. User interface home \& frequently used menu on the left

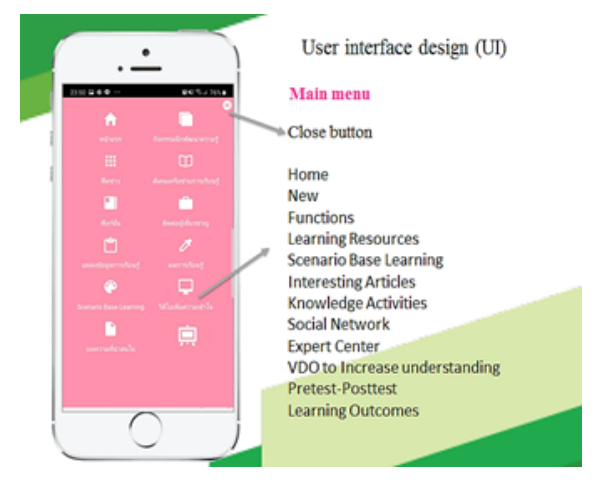

a

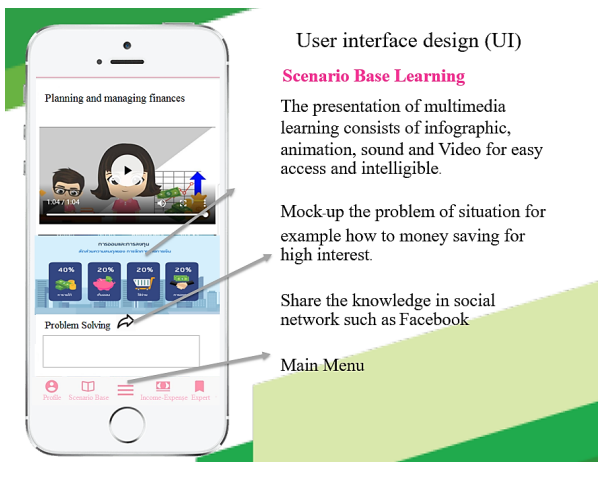

b

Fig. 6. User interface mobile learning financial management following the needs of the respondents 


\subsection{Interview responses}

The semi-structured interviews purposively sampled 10 persons with the following selection criteria:

- Currently a teacher in the Office of the Basic Education Commission

- Must have at least 5 years teaching experience in financial management

- Willing to cooperate in the research

From the interviews with the 10 instructors concerning the teaching and learning factors which affected financial management, all instructors interviewed answered that the main problem was that the students did not realize the value of money Also, it was agreed that technology should be used for teaching anywhere and anytime, which is convenient for cultivating sound financial behavior. This study demonstrated consistency with mobile learning that enables learners to learn anywhere, anytime, helping to cultivate savings and financial management discipline [27]. The researchers analyzed the important issues of the interview results and categorized them according to the 4 main issues of design and mobile application development learning to promote youth financial management competency with the following detailed statements by instructors (see Table 5).

Table 5. Instructors representative answers

\begin{tabular}{|c|c|}
\hline $\begin{array}{l}\text { Teaching and learn- } \\
\text { ing which affected } \\
\text { financial } \\
\text { management. }\end{array}$ & Sample views \\
\hline Teaching & $\begin{array}{l}\text { The teaching of financial management was not the main course but was a supple- } \\
\text { ment to some subjects such as economics by teaching the sufficiency economy } \\
\text { principle, mathematics problems of which the students realize the financial man- } \\
\text { agement effect and also the class teacher advised the students as to how to record } \\
\text { the income account weekly through their mobile application. }\end{array}$ \\
\hline $\begin{array}{l}\text { factors of financial } \\
\text { management promo- } \\
\text { tion }\end{array}$ & $\begin{array}{l}\text { The factors of financial management promotion according to the respondents } \\
\text { consisted of the following: 1) teaching and learning media such as mobile applica- } \\
\text { tions, video clips from internet. 2) the present scenario integrated with financial } \\
\text { management content in an order that the students understood more. 3) practice by } \\
\text { learners. 4) the discipline of the financial payment plan. }\end{array}$ \\
\hline Problem Founds & $\begin{array}{l}\text { The problem at present as regards the promotion of financial management compe- } \\
\text { tency from the interviewees' experience found that the main problem was that the } \\
\text { students did not realize the value of money and the important issue was that no } \\
\text { policy was set up for the financial management course in the curriculum clearly, } \\
\text { and also no technology was applied in the teaching and learning anywhere and } \\
\text { anytime which was convenient for cultivating good financial behavior. }\end{array}$ \\
\hline $\begin{array}{l}\text { Regarding the sugges- } \\
\text { tions }\end{array}$ & $\begin{array}{l}\text { The suggestions for teaching and learning financial management promotion among } \\
\text { the youths, most of the interviewees suggested the following methods: 1) create } \\
\text { and select various media appropriate to the learners, easy to understand, short and } \\
\text { suitable for the present period such as mobile applications, cartoons, videos con- } \\
\text { cerning financial management which apply to their daily lives. 2) teach financial } \\
\text { planning from childhood and build saving discipline and also plan weekly or } \\
\text { monthly payment for students. 3) Integrate the subject with every other subject. 4) } \\
\text { It is suggested that students join the financial campaign by learning mobile learn- } \\
\text { ing technology through interaction and by sharing comments. }\end{array}$ \\
\hline
\end{tabular}


4.7 The research results for research question 2: the confirmatory factors affecting financial management competency

Results shown in Figure 7 suggests that all four independent variables were of the confirmatory factors of the model of financial management competency. Confirmatory factor analysis with Lisrel program of financial management competency consists of 4 factors:

- Money and transactions (MNTS) comprising financial knowledge, income, payment, purchases and prices. Also, records of revenue - expenditure and exchange rates

- Planning and managing finances (FPMN) revenue and expenditure, saving and investment, long term planning and credit management

- Risk and reward (RSRW)

- Financial health (FNHE)

Each section covers awareness, understanding, skills and behavior and good financial health. Analysis of the variable relations by the Pearson-product moment correlation found that the financial management was measured from 30 observed variables as shown that the Pearson-product moment correlation had different statistically significant values at 0.01 and Bartlett's Test of Sphericity $=9616.945, \mathrm{df}=435, \mathrm{p}=0.000$ and $\mathrm{KMO}=0.911$ showed that the matrix correlation of the observed variables of financial management competency analyzed the factors. Therefore, financial management competency had construct validity. The findings of this study, it can be concluded that these 4 above-mentioned factors resulted in the students being able to achieve financial competency is the knowledge, skill, and ability or the financial potential of youth. It is possible to practice the behavior of being well disciplined in saving and managing finances well through learning on a mobile application that can be applied in real life. 


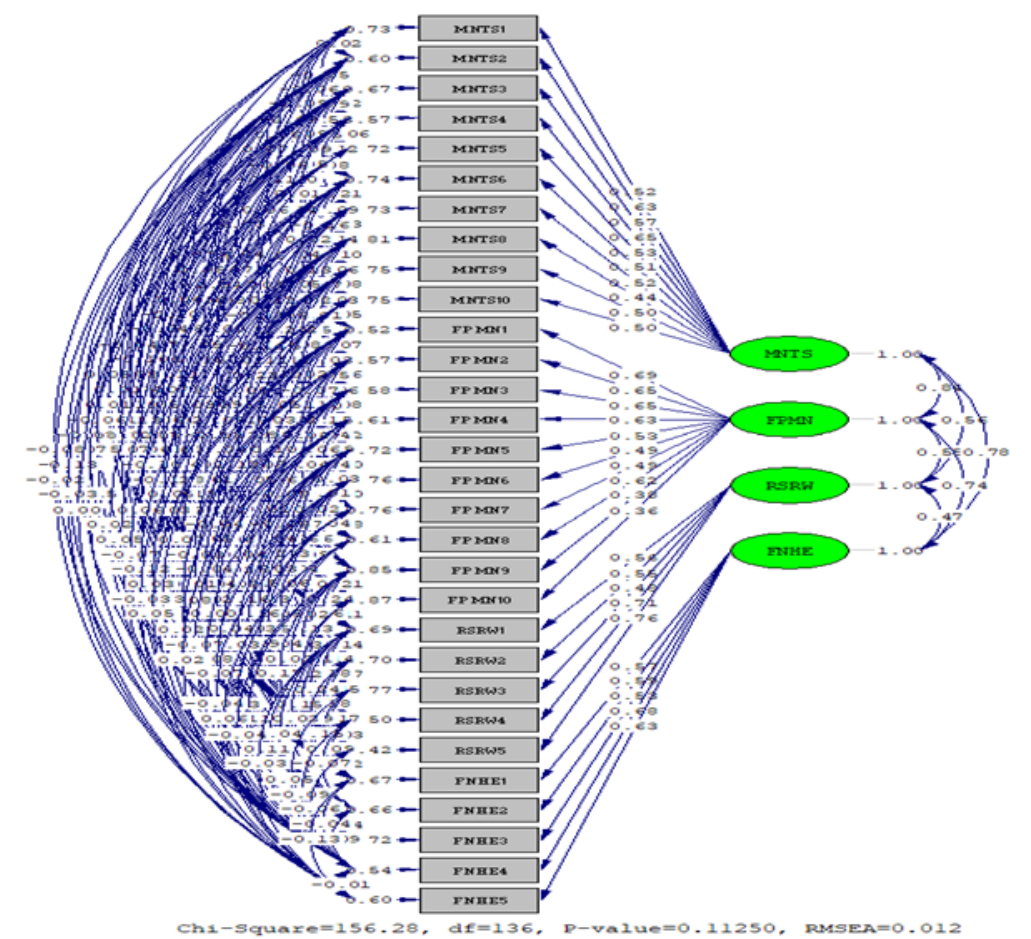

Fig. 7. Analysis of the results of the confirmatory factors of the model of financial management competency

\section{Discussion}

The results of this study on the needs regarding a mobile application leading to the development of a mobile application for promoting financial management competency revealed that most of the learners owned a smart mobile phone $(98.75 \%)$ connected with learning spaces of financial management teaching and learning and could learn anywhere and anytime so as to cultivate appropriate financial behavior, as well as build immunity and good financial skills, to be able to cope with any monetary challenges. Furthermore, the findings of this study, like other studies, emphasize the assertion that the major advantage that made m-learning so popular today is encourages an anywhere-anytime learning habit [13], [17], [28]. This means the learners cultivate the habit of financial management when they grew up and could apply it to their lives and security in the future [21]. The mobile application was developed for easy usage by the program design for the record of the income and expenses of daily life on mobile application as this was the highest need. (PNIModified $=0.80$ ) [29]. The interface was made to meet the needs of users as well as have various types of media such as infographics, animation, sound and video to be intelligible and interesting (64.41\%) [17], to obtain learning resources with it being possible to share these materials with other students using mobile applications, web boards, and social networks, increasing 
the collaboration between peers and peers, and peers and experts, and pretest-posttest [30], [31]. It additionally increased the communication function to contact the financial experts advising on scaffolding the financial knowledge on the application at the highest level $(60.29 \%)$.

In this study, like those reported by [32], the suggested these findings show that students can find self-monitoring scaffolding useful in problem-base learning solving, and increased the mock up of activities according to the scenario which learners could practice to solve the problems such as solving problems and then sharing with others in social networks such as Line, Facebook etc. at the highest level (84.64\%). This also concurs with Seddon, Learning based financial management situations leading to problem solving for learners are often used to develop the potential and skills of students in facing real problems encountered in daily life. This study demonstrated consistency with scenario-based learning to promote youth financial management competency [32], [33].

However, to answer research question 2, the researcher analyzed the confirmatory factors of the model of financial management competency, The findings of this study, like many other studies, also revealed that the variables of money, business plan, financial management, risk and financial health could promote financial management capacity for daily life [1],[2], [34]. The results also revealed that the mobile learning application model has the potential to take education out of the classroom boundaries, and into social networks and social sharing and for the student to access vast content learning sources for cultivating sound habits in financial management as they grow up.

\section{Conclusion and Future Work}

The designed study investigated the comments on the needs and how at present they were practiced and used to develop a mobile application to promote financial management competency and financial management for the youth. Regarding the design and mobile application development, the research found that the learners who needed the application were ready to learn anywhere and anytime a their convenience [35], [36] and they handled the mobile phone all the time.

In this study, much like other studies with the same characteristics, the mobile learning application was designed to support the smart phone on the iOS (Apple) and Android systems. The mobile application of multimedia type had the infographics, animation, sound and video to be intelligible and interesting [15], [20]. The scaffolding application type was that of a social network online through which the learners could exchange data and also connect with financial experts including consultation with financial experts. In addition, it could support jobs from long distances and different locations [37]. Furthermore, it had the social share function which could be shared to various media and the mock-up function for the financial pretest which stimulates their attention. 
Future studies could use the critical factors of mobile learning applied in other teaching courses of life skills. Here the focus is not just on knowledge, but as skills to learn throughout life. In addition, the school does not teach this area, but it is essential for in future life. Furthermore, it is clear from the user experience results that this method is suitable for the youth. This means that the design is easy to use, using a little personal skill. The sequence of steps for using the program must also not be complicated. Therefore, it will be of interest for future studies to be apply mobile learning to 21 st century courses and skills [38] similar to financial management skills which are very knowledgeable about financial, economics, business and entrepreneurial literacy. To enable learners to have an additional learning source that is easily accessible and suitable for today's life, the smartphone, as part of everyday life, cultivates behavior and further develops the skills required for successful living and working in modern times.

\section{$7 \quad$ Acknowledgements}

The researcher greatly appreciates the National Research Council of Thailand for the "research support under the plan of capacity promotion and new generation of researchers following the research and innovation strategy for master and doctoral degree of the year 2019 from the National Research Council of Thailand."

\section{$8 \quad$ References}

[1] OECD. (2015). OECD/INFE Toolkit For Measuring Financial Literacy And Financial Inclusion: 2 rue Andre-Pascal, 75775 Paris cedex 16, France. https://doi.org/10.1787/97892 64254855-10-en

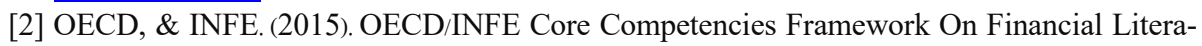
cy For Youth.

[3] Lusardi, A. (2015). Financial Literacy Skills for the 21st Century: Evidence from PISA. The Journal of Consumer Affairs, 49, 639-659. https://doi.org/10.1111/joca.12099.

[4] Lusardi, A., \& Mitchell, O. S. (2014). The economic importance of financial literacy: Theory and evidence. Journal of economic literature, 52(1), 5-44. https://doi.org/10.1257/jel.52.1.5

[5] Traipobsakul, S. (2016). SME Thailand. Magazine of SME Thailand, issue of February 2016.

[6] National Research Council of Asia. (2015). Project "Literacy Improvement for better Finance in Thailand: LIFT) "Citi Foundation, Bangkok.

[7] The National Statistical Office, Economic and Social Statistical Office (2016). The 2018 Household Survey on the use of Information and Communication Technology. The Statistical Forecasting Division, The National Statistical Office, Bangkok.

[8] Bank of Thailand (2013). Report of Skill Survey of Thailand Year 2013. Financial Consumer Protection Centre, Promote knowledge of financial complain, Bangkok.

[9] Alqahtani, M., \& Fayyoumi, A. (2015). Mobile Application Development for Quran Verse Recognition and Interpretations. International Journal of Interactive Mobile Technologies, 9(1), 19-22. https://doi.org/10.3991/ijim.v9i1.4171 
[10] Berkman-Chardon, A., Harel, D., Goel, Y., Marelly, R., Szekely, S., \& Weiss, G. (2016). Scenario-Based Programming for Mobile Applications. IEEE/ACM International Conference on Mobile Software Engineering and Systems, 161-172. https://doi.org/10.11 45/2897073.2897080.

[11] Al-Harrasi, H., Al-Khanjari, Z. \& Sarrab, M. (2015). Proposing a new design approach for M-learning applications. International Journal of Software Engineering and its Application, 9(11), 11-24. https://doi.org/10.14257/ijseia.2015.9.11.02

[12] Kaewkiriya, T. (2010). "e-Learning Change to M-Learning in the Society of Wireless Borderless Communication", Rompreuk Magazine, Year 28, Issue 2009 - 2010.

[13] Khlaisang, J. (2018). Ubiquitous Technology Enhanced Learning : The Outcome-Based Learning Design for 21st Century Learners. Educational Invention and Innovation Research Unit, Faculty of Education, Chulalongkorn University, Bangkok. 95-96.

[14] Tarute, A., Nikou, S., \& Gatautis, R. (2017). Mobile application driven consumer engagement. Telematics and Informatics, 34(4), 145-156. https://doi.org/10.1016/j.tele.20 $\underline{17.01 .006}$

[15] Viswanathan, P. (2016). What is a Mobile Application. Retrieved 10 May 2017, from https://www.lifewire.com/what-is-a-mobile-application-2373354.

[16] Sulisworo, D., Ishafit, I., \& Firdausy, K. (2016). The Development of Mobile Learning Application using Jigsaw Technique. International Journal of Interactive Mobile Technologies, 10(3), 11-16. https://doi.org/10.3991/ijim.v10i3.5268

[17] Drigas, A., \& Angelidakis, P. (2017). Mobile applications within education: An overview of application paradigms in specific categories. International Journal of Interactive Mobile Technologies, 11(4), 17-29. https://doi.org/10.3991/ijim.v11i4.6589

[18] Naismith, L., \& Corlett, D. (2006). Reflections on success: A retrospective of the mLearn conference series 2002-2005. In mLearn 2006: Across generations and cultures, (pp. 29pages)

[19] Alnuaim, A., Caleb-Solly, P., \& Perry, C. (2016). Enhancing student learning of humancomputer interaction using a contextual mobile application. In 2016 SAI Computing Conference (SAI) (pp. 952-959). IEEE. doi: 978-1-4673-8460-5/16/\$31.00. https://doi.org/10. $\underline{1109 / \text { sai.2016.7556095 }}$

[20] SCI. (2016). Mobile Application Development. Retrieved 10 May 2018, from http://www.interlinks.in/mobile-app.php.

[21] Sutherland, R., et al. (2004). "Transforming teaching and learning: embedding ICT into everyday classroom practices," Journal of Computer Assisted Learning, Vol. 20, pp. 413-425, 2004. https://doi.org/10.1111/j.1365-2729.2004.00104.x

[22] Turner, R.C., Mulvenon, S.W., Thomas, S.P. and Balkin, R.S. (2002). Computing Indices of Item Congruence for Test Develpoment Validity Assessments. Retrieved on September 2019 form https://www2.sas.comproceedings/sugi27/p255-27.pdf.

[23] Vongvanich, S. (2015). "The Research of Need Evaluation" Bangkok: Chulalongkorn University Press.

[24] Hair, J. F., Black, W. C., Babin, B. J. \& Anderson, R.E. (2010). Multivariate data analysis: A global perspective. Upper Saddle River NJ: Pearson.

[25] Papadakis, S., Kalogiannakis, M., \& Zaranis, N. (2018). Educational apps from the Android Google Play for Greek preschoolers: A systematic review. Computers \& Education, 116, 139-160. https://doi.org/10.1016/j.compedu.2017.09.007

[26] Hiniker, A., Sobel, K., Hong, S. R., Suh, H., Kim, D., \& Kientz, J. A. (2015, June). Touchscreen prompts for preschoolers: designing developmentally appropriate techniques for teaching young children to perform gestures. In Proceedings of the 14th International 
Conference on Interaction Design and Children (pp. 109-118). ACM. https://doi.org/10.1145/ 2771839.2771851

[27] Papadakis, S., Kalogiannakis, M., Sifaki, E., \& Vidakis, N. (2017). Access moodle using smart mobile phones. A case study in a Greek University. In Interactivity, Game Creation, Design, Learning, and Innovation (pp. 376-385). Springer, Cham. https://doi.org/10.1007/97 8-3-319-76908-0 36

[28] Ke, F. (2008). Computer games application within alternative classroom goal structures: cognitive, metacognitive, and affective evaluation. Educational Technology Research and Development, 56(5-6), 539-556. https://doi.org/10.1007/s11423-008-9086-5.

[29] Page, J. (2013). Financial training for exonerees awaiting compensation: A case study. Journal of Offender Rehabilitation, 98-118. https://doi.org/10.1080/10509674.2012. 750638.

[30] Khlaisang, J., \& Koraneekij, P. (2012, June). Development of blended e-learning model using online interactive reflective learning logs to enhance faculty of education students' inquiring mind and retention at Chulalongkorn University. In International e-Learning Conference 2012 (IEC2012).

[31] Persson, V., \& Nouri, J. (2018). A systematic review of second language learning with mobile technologies. International Journal of Emerging Technologies in Learning (iJET), 188210. https://doi.org/10.3991/ijet.v13i02.8094

[32] Shin, S., \& Song, H. D. (2016). Finding the optimal scaffoldings for learners' epistemological beliefs during ill-structured problem solving. Interactive Learning Environments, 24(8), 2032-2047. https://doi.org/10.1080/10494820.2015.1073749

[33] Seddon, J. M., McDonald, B., \& Schmidt, A. L. (2012). ICT-supported, scenario-based learning in preclinical veterinary science education: Quantifying learning outcomes and facilitating the novice-expert transition. Australasian Journal of Educational Technology, 214-231. https://doi.org/10.14742/ajet.870

[34] Brown, M., Cage, K., Rullan, S., \& Thompson, J. (2016). Scenario-based-learning. Massey University University of New Zealand.

[35] Hebert, S., \& Gyarmati, D. (2014). Financial capability and Essential Skills: An exploratory analysis. Social Research and Demonstration Corporation.

[36] Berkman-Chardon, A., Harel, D., Goel, Y., Marelly, R., Szekely, S., \& Weiss, G. (2016). Scenario-Based Programming for Mobile Applications. IEEE/ACM International Conference on Mobile Software Engineering and Systems, 161-172. https://doi.org/10.11 45/2897073.2897080

[37] Karkar, A., \& Al Ja'am, J. (2016). An educational ontology-based m-learning system. International Journal of Interactive Mobile Technologies, 10(4), 48-56. https://doi.org/10.39 91/ijim.v10i4.6011

[38] Lusardi. (2015). Financial Literacy Skills for the 21st Century: Evidence from PISA. The Journal of Consumer Affairs, 49, 639-659. https://doi.org/10.1111/joca.12099.

\section{Authors}

Alisa Mueangpud is a doctoral student at the Department of Educational Technology and Communications, Faculty of Education, Chulalongkorn University, Thailand.

Jintavee Khlaisang is an Associate Professor at the Department of Educational Technology and Communications, Faculty of Education and Educational Invention and Innovation Research Unit, Chulalongkorn University, Bangkok, Thailand (jintavee.m@.chula.ac.th).

Prakob Koraneekij is an Associate Professor at the Department of Educational Technology and Communications, Faculty of Education and Educational Invention 
Paper-Mobile Learning Application Design to Promote Youth Financial Management Competency in...

and Innovation Research Unit, Chulalongkorn University, Bangkok, Thailand. (Prakob.K@Chula.ac.th).

Article submitted 2019-07-24. Resubmitted 2019-10-02. Final acceptance 2019-10-03. Final version published as submitted by the authors. 